\title{
Abstract \\ Effect of Sandblasting on the Long-Term Corrosion Resistance of Ti G4 in Artificial Saliva ${ }^{+}$
}

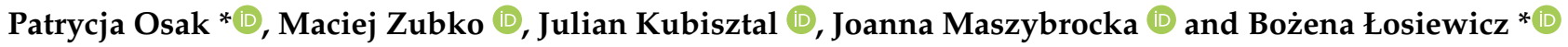 \\ Faculty of Science and Technology, Institute of Materials Engineering, University of Silesia in Katowice, \\ 75 Pułku Piechoty 1A, 41-500 Chorzów, Poland; maciej.zubko@us.edu.pl (M.Z.); \\ julian.kubisztal@us.edu.pl (J.K.); joanna.maszybrocka@us.edu.pl (J.M.) \\ * Correspondence: patrycja.osak@us.edu.pl (P.O.); bozena.losiewicz@us.edu.pl (B.Ł.) \\ + Presented at the First Corrosion and Materials Degradation Web Conference, 17-19 May 2021; \\ Available online: https://cmdwc2021.sciforum.net/.
}

check for

updates

Citation: Osak, P.; Zubko, M.; Kubisztal, J.; Maszybrocka, J.;

Łosiewicz, B. Effect of Sandblasting on the Long-Term Corrosion Resistance of Ti G4 in Artificial Saliva. Mater. Proc. 2021, 6, 5. https:// doi.org/10.3390/CMDWC2021-09985

Academic Editor: Cuie Wen

Published: 8 May 2021

Publisher's Note: MDPI stays neutral with regard to jurisdictional claims in published maps and institutional affiliations.

Copyright: (c) 2021 by the authors. Licensee MDPI, Basel, Switzerland. This article is an open access article distributed under the terms and conditions of the Creative Commons Attribution (CC BY) license (https:// creativecommons.org/licenses/by/ $4.0 /)$.

\begin{abstract}
Titanium Grade 4 (G4) is the most commonly used material for dental implants due to its excellent biocompatibility and mechanical properties. However, titanium implants require a rough surface that can increase the biomechanical potential of implant-bone contact and affect protein adsorption speed. In this work, the effect of sandblasting of the Ti G4 surface on the long-term corrosion resistance in artificial saliva of $\mathrm{pH}=7.4$ at $37^{\circ} \mathrm{C}$ was studied. The X-ray diffraction (XRD) single- $\{\mathrm{hkl}\} \sin ^{2} \psi$ method was used to measure the sandblasted Ti residual stress. In vitro corrosion resistance tests were conducted for 21 days using the open circuit potential method, polarization curves, and electrochemical impedance spectroscopy. Using the Kelvin scanning probe, the electron work function was determined. Analysis of the obtained results showed an improvement in the corrosion resistance of the sandblasted Ti G4 compared to Ti with the machine surface. The increase in corrosion resistance was related to the residual compressive stress of $324.7 \mathrm{MPa}$ present in the sandblasted Ti surface. Sandblasting caused plastic deformation of the Ti surface, which resulted in the improvement in mechanical properties, as evidenced by the increase in the hardness of the sandblasted Ti compared to Ti with the machine surface.
\end{abstract}

Keywords: corrosion resistance; sandblasting; titanium

Supplementary Materials: The conference presentation file is available at https:/ www.mdpi.com/ article/10.3390/CMDWC2021-09985/s1.

Institutional Review Board Statement: Not applicable.

Informed Consent Statement: Not applicable.

Data Availability Statement: Not applicable. 